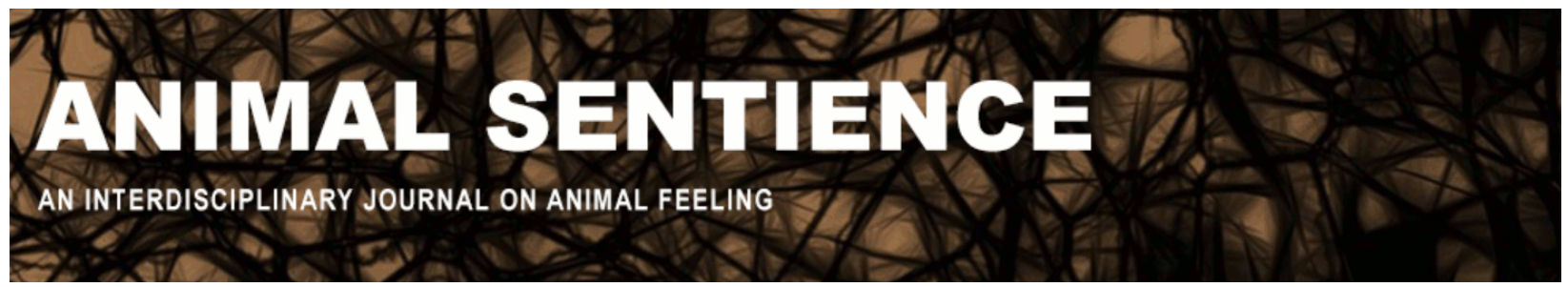

Woodruff, Michael L. (2018) Pain in fish: Evidence from peripheral nociceptors to pallial processing. Animal Sentience 21(2)

DOI: $10.51291 / 2377-7478.1321$

Date of submission: 2018-05-08

Date of acceptance: 2018-05-11

(c)

This article has appeared in the journal Animal

Sentience, a peer-reviewed journal on animal

cognition and feeling. It has been made open access,

free for all, by WellBeing International and deposited

in the WBI Studies Repository. For more information,

please contact

wbisr-info@wellbeingintl.org.

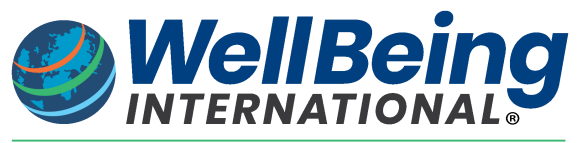

SOLUTIONS FOR PEOPLE, ANIMALS AND ENVIRONMENT 


\title{
Pain in fish: Evidence from peripheral nociceptors to pallial processing
}

\author{
Commentary on Sneddon et al. on Sentience Denial
}

\author{
Michael L. Woodruff \\ Department of Biomedical Sciences \\ East Tennessee State University
}

\begin{abstract}
The target article by Sneddon et al. (2018) presents convincing behavioral and pharmacological evidence that ray-finned fish consciously perceive noxious stimuli as painful. One objection to this interpretation of the evidence is that the fish nervous system is not complex enough to support the conscious experience of pain. Data that contradict this objection are presented in this commentary. The neuroanatomy and neurophysiology of the fish nervous system from the peripheral nerves to the pallium is able to support the sentient appreciation of pain.
\end{abstract}

Michael L. Woodruff is Professor Emeritus of Biomedical Sciences at East Tennessee State University. His research interests include cognitive neuroscience evolutionary psychology and the philosophy of mind.

michaelwoodruff.academia.edu/

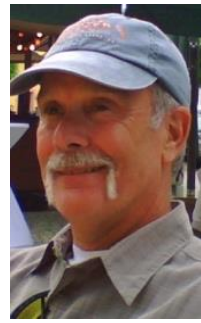

In two recent articles (Woodruff 2017, 2018), I presented neuroanatomical and neurophysiological evidence that the brain of ray-finned fishes is sufficiently complex to support sentience. I did not discuss whether this evidence specifically included the conscious experience of pain. This evidence will be briefly summarized in this commentary.

Sneddon et al. (2018) offer a significant quantity of data leading to the conclusion that sentience in fish includes the experience of pain. Others (e.g., Key 2016; Rose 2007) dispute this conclusion. They claim that all behaviors exhibited by fishes in response to noxious stimuli are reflexive.

Sneddon and her colleagues have shown that A-delta $(A \delta)$ fibers associated with fast, sharp pain and C-fibers associated with slow, burning pain are present in the trigeminal nerve of trout (Ashley et al. 2007; Sneddon 2003; Sneddon et al. 2003). However, the density of C-fibers is a fraction of that found in mammals. Rose uses this observation to claim that fish do not consciously suffer from pain, supporting his argument by noting that sea urchin and sea catfish spines are found in the mouths and throats of predatory marine fishes.

However, the combination of the presence of spines in the mouth of fishes and the comparative reduction in C-fibers does not necessarily imply that fish lack the capability to experience pain. Another plausible interpretation is that evolutionary pressure on predatory fishes maximized their ability to select prey by reducing the number of nociceptors in the mouth and throat, areas supplied by the sensory branches of the trigeminal nerve. That this is a reasonable explanation is suggested by the observation that a mutation in the nociceptors of 
grasshopper mice renders them impervious to the noxious qualities of the toxin of bark scorpions, one of their preferred foods, while they retain pain-guarding responses to injections of formalin (Rowe et al. 2013).

Electrophysiological studies indicate that fish have functional peripheral nociceptors serving the body and tail. These studies also show that nociceptive input reaches the telencephalon, including the pallium. Dunlop and Laming (2005) recorded neuronal responses to pin-prick to the body of goldfish and trout. Analysis of spike conduction velocities indicated responses to both $A \delta$ - and $\mathrm{C}$-fiber activation in the cerebellum, tectum and telencephalon in trout, and in the cerebellum and tectum in goldfish. Interestingly, only longer latency responses attributable to $\mathrm{C}$-fiber activation occurred in the goldfish telencephalon. These data indicate that there is central processing of nociceptive input and suggest a species difference in pain processing in the telencephalon.

Unfortunately, Dunlop and Laming did not specify the location of the telencephalic recording sites. Nordgreen et al. (2007), however, inserted electrodes specifically into the dorsal telencephalon of the Atlantic salmon and recorded sensory evoked potentials (SEPS) to noxious electrical shocks to the tail base. Analysis of the SEPs indicated pallial processing of input originating from $A \delta$ - and C-fibers.

Ludvigsen et al. (2014) extended these findings. They recorded tail-shock-induced SEPS from the surface of the skull of Atlantic cod. The amplitudes and latencies of the SEPs indicated pallial responses attributable to peripheral $A \delta$ - and C-fiber activation. Ludvigsen et al. also found stimulus-related changes in electrical activity that continued for as long as $240 \mathrm{msec}$. SEP activity of this duration suggests substantial associative neuronal processing related to elaboration of the nociceptive properties of the stimulus (Zaslanskya et al. 1996).

In sum, then, the complexity of neurophysiological activity from peripheral nerves to the pallium supports the argument by Sneddon et al. (2018) that fishes consciously experience pain.

\section{References}

Ashley, P. J., Sneddon, L. U. and McCrohan, C. R. (2007). Nociception in fish: Stimulus-response properties of receptors on the head of rainbow trout, Oncorhynchus mykiss. Brain Research, 1166: 47-55.

Dunlop, R. and Laming, P. (2005). Mechanoreceptive and nociceptive responses in the central nervous system of goldfish (Carassius auratus) and trout (Oncorhynchus mykiss). Journal of Pain, 6: 561-568.

Key, B. (2016). Why fish do not feel pain. Animal Sentience 3(1). 
Ludvigsen, S., Stenklev, N. C., Johnsen, H. K., Laukli, E., Matre, D. and Aas-Hansen, Ø. (2014). Evoked potentials in the Atlantic cod following putatively innocuous and putatively noxious electrical stimulation: A minimally invasive approach. Fish Physiology and Biochemistry, 40: 173-181.

Nordgreen, J., Horsberg, T. E., Ranheim, B. and Chen, A. C. N. (2007). Somatosensory evoked potentials in the telencephalon of Atlantic salmon (Salmo salar) following galvanic stimulation of the tail. Journal of Comparative Physiology. A, Neuroethology, Sensory, Neural, and Behavioral Physiology, 193: 1235-1242.

Rose, J. D. (2007). Anthropomorphism and 'mental welfare' of fishes. Diseases of Aquatic Organisms, 75: 139-154.

Rowe, A. H., Yucheng Xiao, Y., Rowe, M. P., Cummins, T. R. and Zakon, H. H. (2013). Voltagegated sodium channel in grasshopper mice defends against bark scorpion toxin. Science, 342: 441-446.

Sneddon, L. U. (2003). The evidence for pain in fish: The use of morphine as an analgesic. Applied Animal Behaviour Science, 83: 153-162.

Sneddon, L. U., Braithwaite, V. A. and Gentle, M. J. (2003). Do fish have nociceptors: Evidence for the evolution of a vertebrate sensory system. Proceedings of the Royal Society London B: Biological Sciences, 270: 1115-1121.

Sneddon, L. U., Lopez-Luna, J., Wolfenden, D. C. C., Leach, M. C., Valentim, A. M., Steenbergen, P. J., Bardine, N., Currie, A. D., Broom, D. M. and Brown, C. (2018). Fish sentience denial: Muddying the waters. Animal Sentience 21(1).

Woodruff, M. L. (2017). Consciousness in teleosts: There is something it feels like to be a fish. Animal Sentience 13(1).

Woodruff, M. L. (2018). Sentience in fishes: More on the evidence. Animal Sentience 13(16).

Zaslanskya, R., Sprecherb, E., Tenkec, C. E., Hemlib, J. A. and Yarnitsky, D. (1996). The P300 in pain evoked potentials. Pain, 66: 39-49. 


\section{UQÀM/ISC Cognitive Science Summer School June 26 - July 6 2018, Montreal, Canada The Other Minds Problem: Animal Sentience and Cognition}

Overview. Since Descartes, philosophers know there is no way to know for sure what - or whether - others feel (not even if they tell you). Science, however, is not about certainty but about probability and evidence. The 7.5 billion individual members of the human species can tell us what they are feeling. But there are 9 million other species on the planet (20 quintillion individuals), from elephants to jellyfish, with which humans share biological and cognitive ancestry, but not one other species can speak: Which of them can feel — and what do they feel? Their human spokespersons - the comparative psychologists, ethologists, evolutionists, and cognitive neurobiologists who are the world's leading experts in "mind-reading" other species -- will provide a sweeping panorama of what it feels like to be an elephant, ape, whale, cow, pig, dog, bat, chicken, fish, lizard, lobster, snail: This growing body of facts about nonhuman sentience has profound implications not only for our understanding of human cognition, but for our treatment of other sentient species.

Gregory Berns: Decoding the Dog's Mind with Awake Neuroimaging

Gordon Burghardt: Probing the Umwelt of Reptiles Jon Sakata: Audience Effects on Communication Signals PANEL: Reptiles, Birds and Mammals WORKSHOP: Kristin Andrews: The "Other" Problems:

Mind, Behavior, and Agency

Sarah Brosnan: How Do Primates Feel About Their Social Partners?

Alexander Ophir: The Cognitive Ecology of Monogamy Michael Hendricks: Integrating Action and Perception in a Small Nervous System

PANEL: Primates, Voles and Worms

WORKSHOP: Jonathan Birch: Animal Sentience and the Precautionary Principle

Malcolm MacIver: How Sentience Changed After Fish Invaded Land 385 Million Years Ago

Sarah Woolley: Neural Mechanisms of Preference in Female Songbird

Simon Reader: Animal Social Learning: Implications for Understanding Others

PANEL: Sea to Land to Air

WORKSHOP: Steven M. Wise: Nonhuman Personhood

Tomoko Ohyama: Action Selection in a Small Brain

(Drosophila Maggot)

Mike Ryan: "Crazy Love": Nonlinearity and Irrationality in

Mate Choice

Louis Lefebvre: Animal Innovation: From Ecology to

Neurotransmitters

PANEL: Maggots, Frogs and Birds: Flexibility Evolving

SPECIAL EVENT: Mario Cyr: Polar Bears

Colin Chapman: Why Do We Want to Think People Are

Different?

Vladimir Pradosudov: Chickadee Spatial Cognition

Jonathan Balcombe: The Sentient World of Fishes

PANEL: Similarities and Differences

WORKSHOP (part 1): Gary Comstock: A Cow's Concept of

Her Future

WORKSHOP (part 2): Jean-Jacques Kona-Boun: Physical and

Mental Risks to Cattle and Horses in Rodeos
Joshua Plotnik: Thoughtful Trunks: Application of Elephant Cognition for Elephant Conservation

Lori Marino: Who Are Dolphins?

PANEL: Mammals All, Great and Small

Larry Young: The Neurobiology of Social Bonding, Empathy and Social Loss in Monogamous Voles

WORKSHOP: Lori Marino: The Inconvenient Truth About

Thinking Chickens

Andrew Adamatzky: Slime Mould: Cognition Through

Computation

Frantisek Baluska \& Stefano Mancuso: What a Plant Knows

and Perceives

Arthur Reber: $\underline{\text { A Novel Theory of the Origin of Mind: }}$

Conversations With a Caterpillar and a Bacterium

PANEL: Microbes, Molds and Plants

WORKSHOP: Suzanne Held \& Michael Mendl: Pig

Cognition and Why It Matters

James Simmons: What Is It Like To Be A Bat?

Debbie Kelly: Spatial Cognition in Food-Storing

Steve Phelps: Social Cognition Across Species

PANEL

WORKSHOP: To be announced

Lars Chittka: The Mind of the Bee

Reuven Dukas: Insect Emotions: Mechanisms and

Evolutionary Biology

Adam Shriver: Do Human Lesion Studies Tell Us the Cortex is Required for Pain Experiences?

PANEL

WORKSHOP: Delcianna Winders: Nonhuman Animals in Sport and Entertainment

Carel ten Cate: Avian Capacity for Categorization and

Abstraction

Jennifer Mather: Do Squid Have a Sense of Self?

Steve Chang: Neurobiology of Monkeys Thinking About

Other Monkeys

PANEL

WORKSHOP: The Legal Status of Sentient Nonhuman

Species 